\title{
New insights into the composition of historical remedies and pharmaceutical formulations: the identification of natural resins and balsams by gas chromatographic-mass spectrometric investigations
}

\author{
Francesca Caterina Izzo ${ }^{1}$ (D) Giulia Carolina Lodi ${ }^{1}$ - Maria Luisa Vázquez de Ágredos Pascual ${ }^{2}$
}

Received: 9 July 2020 / Accepted: 28 October 2020 / Published online: 12 December 2020

(C) The Author(s) 2020

\begin{abstract}
The present paper reports one of the first studies on the identification of natural resins and balsams in modern era drug formulations. Gas chromatography coupled with mass spectrometry (GC-MS) was applied to investigate the composition of ancient remedies and pharmaceutical formulations coming from the Spezieria di Santa Maria della Scala in Rome, founded at the end of the seventeenth century by the Discalced Carmelites. The obtained results highlight the presence of complex mixtures containing resinaceous and lipidic-based compounds. Thanks to the detection of characteristic markers, it was possible to identify several natural resins, such as guaiacum resin, ladano resin and scammony resin. Balsamic and aromatic compounds characteristic of essential oils were identified as well. In addition, an anti-inflammatory ointment, composed by mixing Venetian turpentine, a Pinaceae resin and a triterpene resin exudate of a plant from South America, was found among the analysed formulations. Combining the analytical results, the historical research and the botanical composition, it was possible to formulate compositional hypotheses of this historical medicine and provided some indications about their use in health. The study of historical drugs is not only important to know the practices handed down by apothecaries in the past, but also fundamental to reconstruct historical recipes that can inspire new dermatological, cosmetic, hygienic and current curative products.
\end{abstract}

Keywords Historical drugs · Spezieria of Santa Maria della Scala in Rome · Natural organic compounds · GC-MS · Resins · Balsams

\section{Introduction}

Ethnobotanical research on pharmaceutical remedies obtained from medicinal plants is continuously developing, thanks to the understanding of the therapeutic use of these plants and their importance in the historical, geographical, socio-cultural, anthropological and economic fields (Medeiros and De Albuquerque 2012; Reyes-García et al. 2006; Jarić et al.

Francesca Caterina Izzo

fra.izzo@unive.it

1 Sciences and Technologies for the Conservation of Cultural Heritage, Department of Environmental Sciences, Informatics and Statistics, Ca' Foscari University of Venice, Via Torino 155/b, 30174 Venice, Italy

2 Faculty of History and Geography, University of Valencia, Av. Blasco Ibañez 28, 46010 Valencia, Spain
2007; Thomas et al. 2009; Liu et al. 2009; de Albuquerque et al. 2007; Berihuete-Azorín 2013). The testimony of the use of medicinal plants and natural remedies dates back to ancient times. Most of the ancient populations were in close contact with the surrounding environment and from which they took the ingredients to produce remedies, medicines, drugs and products for body care and cosmetics (Jamshidi-Kia et al. 2018). The presence of hallucinogens and numerous other plants, such as aromatic ones (with a structure and chemical composition also similar to the brain hormones), explains the importance they had for medicine in different times and cultures, and the interest that all this has in the field of cultural anthropology. In this sense, the first writing that is an evidence of the use of medicinal plants for the remedy preparation was found on a Sumerian clay slab from Nagpur, dating back to about 5000 years ago (Jamshidi-Kia et al. 2018). The Nippur tablets, dated to the 3rd millennium $\mathrm{BC}$, bring together the oldest known collection of medical prescriptions, closely 
followed by various ancient Egyptian texts including numerous references to mineral and vegetal therapy, such as the Ebers Papyrus, dated around at $1500 \mathrm{BC}$. In these ancient texts, the value and properties attributed to certain medicinal substances are linked to certain gods (Bilimoff 2003), aspects that are maintained over time and that we can still see in the Spezieria of Santa Maria della Scala in Rome, the object of this research. In China, for instance, a few dozen drugs extracted by plants or having an animal origin were already recorded around $1100 \mathrm{BC}$, while in ancient Greece, Hippocrates already discovered the properties of numerous plants in his treatise On Air, Water, and Places, considered the first book on geomedicine and the environment. In the Greco-Roman world, these descriptions were followed by those made by Theosophus of Ephesus (fourth and third century BC), Dioscorides (first century AD), Pliny the Elder (first century AD), Galen (fourth century AD) and Oribasio of Pérgamo (fourth and fifth centuries $\mathrm{AD}$ ) in their respective treatises, among other authors. In fact, ancient Greek culture had the rizotómos, an expert in medicinal herbalism, and the pharmacopoeia, an expert in and seller of plant medicines (Rey 2008; Bennett and Prance 2000). Also in antiquity, but in other non-European cultures, the use of natural therapeutics, based on the properties of plants, was also of great importance, according to Ayurvedic medicine in India, and current healing practices among Australian Aborigines, African communities and American indigenous populations, based in all cases on the knowledge and use of ancient therapeutic remedies, which, again, reminds us of the importance that these studies and field of knowledge have for cultural anthropology. In other words, the use of drugs and psychotropic drugs is relevant in comparative cultural anthropology because the use of one or the other acquires meaning within each socio-cultural worldview, and this from the past to the present.

Returning to Europe, after the fall of the Western Roman Empire (476 AD) and the beginning of the Middle Ages, plant-based substances and formulations continued to have great importance in Western and Eastern Europe (Byzantium), and in both the Christian and Islamic world (Taylor 2016), as evidenced by the treatises of Mesue the Younger (1013), Avicenna (978-1036), Juan Serapion (1070) or Bartholomeus Anglicus (1220), among others. This was also projected in the Modern Era, and between the fifteenth and eighteenth centuries, natural medicine of plant and animal origin coexisted with the mineral. In this sense, it was not until the early Renaissance that hermetic philosophy and alchemy sought to provide a more rational explanation for the healing properties of plants and to explain the importance of mineral and vegetal compounds. The physician and alchemist Paracelsus (c. 1496) was the most outstanding example of scholars in this field. Paracelsus described how certain diseases could be cured with plants that resembled the organ that needed healing (Nitrihual Valdebenito 2015).
The mixtures of various vegetal species, or the mixture of these species with minerals and salts (as with theriac), are understood in alchemical philosophy to possess "body, soul and spirit". In this context (i.e. under the influence of the new pharmaceutical science of Paracelsus), by combining the therapeutic heritage of numerous cultures from East and West (from the Sumerian of the ancient Near East to the Roman, passing through the Babylonian, Persian, Egyptian or Greek, among others), the friars of Santa Maria della Scala of Rome worked in this spezieria preparing drugs between the seventeenth and eighteenth centuries. Therefore, the pharmaceutical formulations that have been preserved here from those centuries, and that we have analysed, should show us this synthesis of substances and traditions from different times and cultures.

In the case of resins, it should not be forgotten that in many ancient cultures, they were interpreted as the vital liquid equivalent to human blood, which they could substitute in numerous rituals and practices.

The importance of these pharmaceutical remedies and cosmetic preparations from a historical, anthropological and social point of view has led to many investigations concerning these materials, also from a scientific point of view. In fact, the chemical investigation of these materials, generally found in ceramic, glass or stone containers, can provide exceptional information regarding both pharmaceutical and technological knowledge and the practices in their use (Ribechini et al. 2008, 2011a; Colombini et al. 2011).

In particular, the analyses related to the organic substances and mixtures appear to be of fundamental importance for identifying the materials, understanding their origin and their use and providing further information also related to everyday life. These are the topics of numerous investigations and works dealing with the characterisation of ancient cosmetics and archaeological residues (Riva 2001; Gamberini et al. 2011; Modugno et al. 2006; Izzo et al. 2013; Saliu et al. 2011; Petrović et al. 2005; GuaschJané et al. 2004; Lucero-Gómez et al. 2014; Mackonochie and Heinrich 2019).

In this research, we studied the organic composition of 8 ancient remedies and pharmaceutical formulations conserved in the cited Spezieria di Santa Maria della Scala in Rome, founded at the end of the seventeenth century by the religious order of the Discalced Carmelites, as previously indicated. As reported in Vázquez de Ágredos Pascual et al. (2018), these friars had the possibility to use vegetal substances and mineral resources from Central and South America, and different regions of India, China and Japan. The Order of Discalced Carmelites, a religious order of Spanish origin, during the seventeenth century controlled trade with the East and West Indies, and at the end of the seventeenth century, they founded the Spezieria di Santa Maria della Scala inside their convent in Rome. In particular, the friars were known to use and mix organic compounds (especially from botanical sources) for their pharmaceutical preparations, in accordance with the most important pharmacopoeias from the post- 
Constantine period, such as Antidotarium Nicolai. From the West Indies, for example, came products such as jalap, guaiacum, hydrastis, ipecacuanha, rathany root and sarsaparilla. For its part, the glass and wooden containers in which the compound drugs and simple substances are preserved at Santa Maria della Scala of Rome mention some of these plant species of American origin, including the guaiacum (Guaiacum officinale L./G. Sanctum L.) or guayacan, palo santo (holy stick) or Indian stick (Bursera graveolens), ipecacuanha root (Carapichea ipecacuanha (Brot.) L. Andersson), coca extract (Erythroxylum coca) and tobacco (Nicotina tabacum).

A first attempt to disclose the composition of un unknown drug formulation from the Spezieria was recently published by Lodi et al. (2020), but further investigations were required in the study of the origin and use of the medicines that have remained inside the containers in the Spezieria for centuries.

However, specific scientific literature provides very limited analytical studies of Modern Age pharmaceutical remedies and drugs. For this reason, this research, and the scientific results it offers, should be considered one of the few contributions to the physicochemical study of medicines prepared with organic compounds in the Modern Age, characterised by being in themselves a melting pot among the ancient therapeutic traditions and the new pharmaceutical science after Paracelsus (Medeiros and De Albuquerque 2012; Brandão et al. 2008).

The new way of treating diseases from Paracelsus, and especially between the Renaissance and the Baroque, is also associated with beliefs linked to a very particular worldview of the drug, deeply rooted in alchemy. In this sense, it was Paracelsus who masterfully incorporated the chemical or al-kémicas laws into the medical or iatrochemical (iatros $=$ medicine) environment while also maintaining all their hermeticism. To do so, he had to carry the alchemical laws to the field of pharmacological medicine under a generic term, spagyric, which he revamped and used to describe "hermetic medicine" and the preparation of the therapeutic remedies that derived from it. Then, between the fifteenth and eighteenth centuries, the practice of preparing certain complex formulations for healing was connected not only to scientific principles, but also to others associated with magical thinking, of great interest to cultural anthropology.

The ancient Spezieria of Santa Maria della Scala in Rome, thus, offers an extraordinary opportunity to widen this knowledge. For this purpose, the present study took into consideration several remedies and pharmaceutical formulations preserved in the main showcase of this historical pharmacy, organic materials used, since ancient times, to prepare incense, medicines, cosmetics and perfumes.

These compounds were analysed by gas chromatography coupled with mass spectrometry (GC-MS) since this technique allows the separation and the identification of organic fractions present in complex organic mixtures by solving the molecular composition of organic materials and their degradation products. Organic fractions are also called biomaterials and are mainly lipids, proteins, vegetable resins, polysaccharides, organic dyes and a variety of plant extracts that have been the main components of cosmetics and pharmaceutical products since ancient times. They consist of complex mixtures of many chemical species, with a wide range of molecular weights, from highly volatile monoterpenes and sesquiterpenes to highly insoluble macromolecules, such as denatured proteins or highly polymerized resins (such as amber). The chemical composition of natural organic materials varies according to the species of animal or vegetable origin, and this complexity increases because often we are faced with their transformation products, mainly due to ageing (Mills and White 1994; Colombini and Modugno 2009).

In Archaeology and Heritage Science, GC-MS identification is often based on the detection of diagnostic molecules named biomarkers. These biomarkers are present intact in the original material, or they are formed over the centuries due to ageing (Colombini et al. 2005). The characteristic biomarkers of the extant species are still recognizable in their fossil counterparts (Simoneit et al. 2016)

In literature, there are several articles on the characterisation of historical organic materials that use this approach, in particular related to the study of ancient cosmetics (Ribechini et al. 2011a; Pérez-Arantegui et al. 2009; Gamberini et al. 2008), of residues found inside an ancient Etruscan plumpekanne (Mizzoni and Cesaro 2007; Colombini et al. 2009) or related to the characterisation of organic components of the original contents of Egyptian ceramic vessels (e.g. natural resins, waxes, bitumen, pitch and lipid materials) (Colombini et al. 2005; Ribechini et al. 2009) or of seven Roman glass unguentaria (Ribechini et al. 2008). Moreover, GC-MS was also employed to characterise and compare the composition of modern and archaeological figs (Ribechini et al. 2011b), historical honey (Oliveira et al. 2019), mummies (Abdel-Maksoud et al. 2019) and dental calculus (Gismondi et al. 2020).

Finally, the study of historical drugs that are preserved in the Spezieria of Santa Maria della Scala in Rome, visited by Popes, the European royalty and nobility of the seventeenth and eighteenth centuries, is not only important to know the practices handed down by apothecaries in the past, but also fundamental to reconstruct historical recipes that can inspire new dermatological, cosmetic, hygienic and current curative products. The complex pharmaceutical formulations, thus, provide a way of knowledge towards the medical science of the past, with keys to the innovation in many pharmaceutical laboratories today.

\section{Materials and methods}

\section{Analysed compounds}

The selection of the organic compounds to be analysed was based on previous results by Vázquez de Ágredos Pascual 
et al. (2017, 2018) obtained by XRD, Raman and FT-IR. They suggested the creation of 7 distinct groups of drugs and pharmaceutical remedies, one mainly characterised by the presence of organic compounds. Organic substances, thus, represent a larger part of the remedies and the pharmaceutical formulations stored in the main showcase of the Antica Spezieria di Santa Maria della Scala in Rome (Fig. 1).

It is interesting to notice that several compounds in group 5 "organic compounds" had both artistic and medicinal uses.

Table 1 reports the list of the organic samples analysed in this paper and their description. These compounds were stored in the main showcase of the salesroom, into sealed containers. The labels reporting their names are partially missing or not clearly readable. They suggest the presence of vegetal resins and balsams.

In Table 1, a brief description of the samples and the images obtained by optical microscopy are reported as well.

\section{GC-MS}

Based on previous results (Vázquez de Ágredos Pascual et al. 2017, 2018), the GC-MS analyses were focused on the identification of natural resins and balsams in the selected drug formulations. A quaternary ammonium salt, namely $\mathrm{m}$ (trifluoromethylphenyl)trimethylammonium hydroxide, $0.2 \mathrm{~N}$ methanolic solution, was chosen since its capability of transesterifying triglycerides, wax esters, phospholipids, steryl esters and etc. and transforming them into their corresponding methyl esters. Small amounts of sample (up to $0.35 \mathrm{mg}$ ) were transesterified by a one-step process using $30 \mu \mathrm{L}$ of $\mathrm{m}$-(trifluoromethyl)phenyltrimethylammonium hydroxide, $2.5 \%$ in methanol, and then $1 \mu \mathrm{L}$ of the derivatised sample was injected in the chromatographic column's head using helium as the carrier gas (flow rate $1.2 \mathrm{~mL} / \mathrm{min}, 99.99 \%$ purity). This method was already successfully tested by authors already on archaeological pitch (Izzo et al. 2013), fatty acids from historical and modern drying and non-drying oils (Fuster-López et al. 2016; Izzo et al. 2014a, b; Fuster-López et al. 2019; Caravá et al. 2020), natural waxes and terpenic resinaceous materials from artistic and archaeological contexts (Izzo et al. 2013, 2017; Rigon et al. 2020), an unknown historical drug formulation from this Spezieria (Lodi et al. 2020).

The GC-MS runs were performed on an Agilent Technologies 6890N (Network GC System) equipped with a mass spectrometric detector Agilent 5973 with a quadrupole analyser. The chromatographic separation was performed on a chemically bonded fused silica capillary DB - 5MS column (30 m length, $0.25 \mathrm{~mm}$ internal diameter, $0.25 \mu \mathrm{m}$ film thickness of stationary phase $-5 \%$ phenyl methyl polysiloxane).

The GC and MS conditions were experimentally set up. The inlet temperature was $290{ }^{\circ} \mathrm{C}$, and the MS interface was at $250{ }^{\circ} \mathrm{C}$. The temperature program was set from 100 to 320 ${ }^{\circ} \mathrm{C}$ with a ramp of $10^{\circ} \mathrm{C} / \mathrm{min}$, and held the temperature for 15 min. The analyses were run using a split injector.

Being untargeted analysis, the MS was run in full scan mode ( $\mathrm{m} / \mathrm{z}$ 50-650), 1.9 scans/s.

Solvent delay was set at $4.5 \mathrm{~min}$. The transfer line was at $240{ }^{\circ} \mathrm{C}$ and the source temperature was $230{ }^{\circ} \mathrm{C}$. Electron ionisation energy was $70 \mathrm{eV}$.

The compounds were identified by the use of the NIST and MS Search 1.7 Library of Mass Spectra, but since commercial MS libraries do not generally include the compounds analysed in this study, MS interpretation and a library created by the authors for natural materials using AMDIS (Automated Mass spectral Deconvolution and Identification System) software were employed as well.

\section{Results and discussion}

Table 2 reports the results obtained by GC-MS analysis. As it can be observed, the samples are characterised by fairly/very complex mixtures of organic compounds. The complexity of the results is reflected in the difficulty in assigning some substances. In fact, the name on the label could not always be used as a key for reading and interpreting the data obtained. In some cases, the label was even absent; in others, no correspondence was found between the reported name and the data

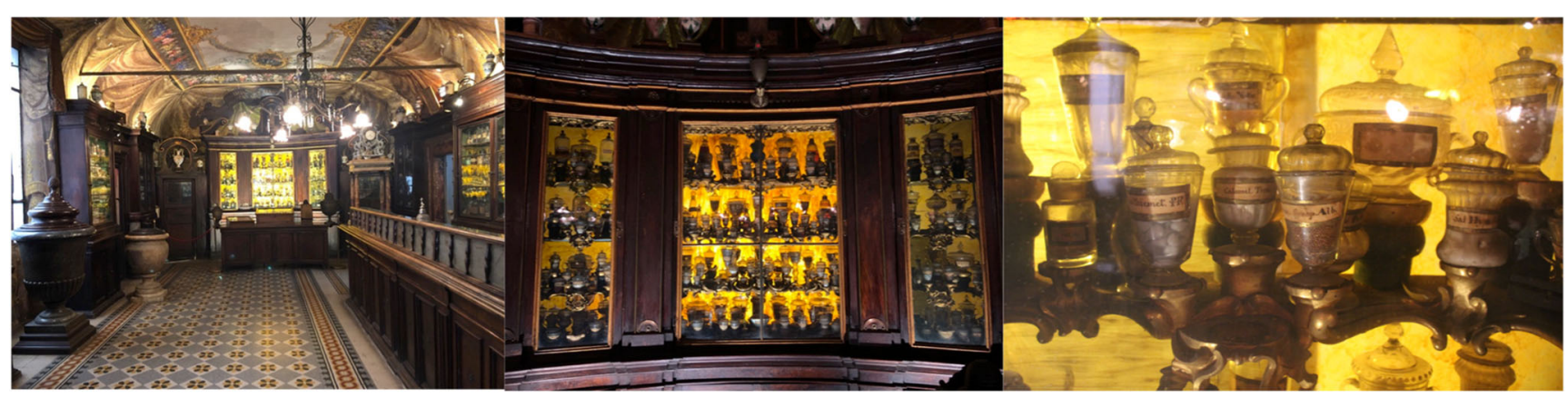

Fig. 1 Spezieria di Santa Maria della Scala salesroom, main showcase and better "glass containers" (no jars) 
Table 1 List of the analysed samples with the names reported in the labels and their description

\begin{tabular}{|c|c|c|c|}
\hline $\begin{array}{l}\text { Sample } \\
\#\end{array}$ & Label & Images & Description \\
\hline 81 & Benzoin & & $\begin{array}{l}\text { A compact piece and tiny, slightly sticky fragments. Brown-reddish colour. } \\
\text { The surface is rough, there appear to be darker micro-included. }\end{array}$ \\
\hline 119 & $\begin{array}{l}\text { Resina } \\
\text { Guajac }\end{array}$ & & $\begin{array}{l}\text { Some small fragments are translucent others have an opaque veil. They } \\
\text { are of different shapes and colours (brown, reddish-brown, red-yellowish, } \\
\text { greyish, and transparent). Slightly sticky. }\end{array}$ \\
\hline 193 & $\begin{array}{l}\text { Guaiaco } \\
\text { Resin }\end{array}$ & & $\begin{array}{l}\text { Small fragments }(\mu \mathrm{m}) \text { of different shape and colour: some are long and } \\
\text { very thin, almost resembling scales, others are more like parallelepipeds. } \\
\text { They range from reddish-brown to yellowish, some are slightly opaque, } \\
\text { others translucent. All present within the micro-bubbles. They are slightly } \\
\text { sticky. }\end{array}$ \\
\hline 171 & Unlabelled & & $\begin{array}{l}\text { A larger and more compact piece accompanied by tiny scales. Uneven } \\
\text { and reddish-brown wrinkled surface in which it seems to accumulate dust } \\
\text { causes yellow reflections (even dusting with the brush you cannot remove } \\
\text { it). The scales are yellowish. }\end{array}$ \\
\hline 174 & $\begin{array}{l}\text { Balsam } \\
\text { S.Ton }\end{array}$ & & $\begin{array}{l}\text { Irregular flakes of light yellow almost white and intense yellow. They have } \\
\text { very small bubbles inside and even the smallest included in a slightly } \\
\text { darker colour. They appear to have a decidedly lower density than that of } \\
\text { the other samples. }\end{array}$ \\
\hline 232 & $\begin{array}{l}\text { Resin } \\
\text { scamon }\end{array}$ & & $\begin{array}{l}\text { Irregular brown fragments with some greenish-yellow reflections. They } \\
\text { have a slight superficial opacity. }\end{array}$ \\
\hline 142 & $\begin{array}{l}\text { Babam } \\
\text { odintalg }\end{array}$ & & $\begin{array}{l}\text { Reddish-brown fragments have a slight opacity. The surface is rough. } \\
\text { Presence of probable internal bubbles. }\end{array}$ \\
\hline 223 & Ladon & & $\begin{array}{l}\text { The sample is composed of a larger body and small fragments that have } \\
\text { become detached irregularly. The largest mass of colour is black and is } \\
\text { completely opaque, it has a pitted appearance. }\end{array}$ \\
\hline
\end{tabular}

obtained. Furthermore, although some of these substances were also used in the artistic field, their use in the pharmacological field has not been completely codified.

Of all the samples analysed, five emblematic examples of pharmaceutical remedies are discussed below, given their particular compositions.

The names of the samples are listed below: LS81 benzoin (the "Sample LS81 benzoin" section), LS119 Resina Guajac and LS193 guaiacol resin (the "LS119 Resina Guajac and LS193 guaiacol resin" section), LS171 unlabelled (the "Samples LS 171 unlabelled" section), LS232 resin scamon and LS223
Ladon (treated in the "LS232 resin scamon and LS223 Ladon" section as complex mixtures), LS142 Babam odintalg and LS174 Balsam S.Ton (treated in the "LS174 Balsam S.Ton and LS142 Babam odintalg” section as aromatic substances).

\section{Sample LS81 benzoin}

The sample analysed through GC-MS presents an interesting chromatographic profile (Fig. 2). As reported in Table 2, mainly oxidised and non-oxidised phenolic compounds and volatile compounds have been identified. 
Table 2 List of the samples, results obtained and GC-MS analysis after transesterification ("ME" stands for methyl esters, "diME" stands for di-methyl esters). The compounds in bold are those more abundant in the chromatograms

\begin{tabular}{|c|c|c|c|c|c|}
\hline Sample \# & Sample name & $\begin{array}{l}\text { RT } \\
(\min )\end{array}$ & Main compounds detected & $\begin{array}{l}\mathrm{m} / \mathrm{z} \text { values of } \mathrm{M}+ \\
\text { (most abundant ion) }\end{array}$ & Considerations \\
\hline \multirow[t]{9}{*}{81} & \multirow[t]{9}{*}{ Benzoin } & $\begin{array}{l}9.57 \\
11.26\end{array}$ & $\begin{array}{l}\text { Benzaldehyde, 4-methoxy } \\
\text { Benzoic acid 4,methoxy ME }\end{array}$ & $\begin{array}{l}136(135) \\
166(135)\end{array}$ & \multirow{9}{*}{$\begin{array}{l}\text { Fairly complex sample containing a mixture } \\
\text { of benzoin resin (styrax) and fatty acids. } \\
\text { Volatile compounds (such as toluene) are } \\
\text { present as well. }\end{array}$} \\
\hline & & 11.42 & Cinnamic acid ME & $162(131)$ & \\
\hline & & 12.62 & Vanillin methylether (veratric aldehyde) & $166(166)$ & \\
\hline & & 12.89 & Terephthalic acid diME & $194(163)$ & \\
\hline & & 13.43 & Toluene & $92(91)$ & \\
\hline & & 13.57 & Benzene, 4-dimethoxymethyl-1,2-dimethoxy & $212(181)$ & \\
\hline & & 13.96 & Veratric acid ME & $196(196)$ & \\
\hline & & 16.71 & Capric acid ME & $186(74)$ & \\
\hline & & 18.69 & Tridecanoic acid ME & $228(74)$ & \\
\hline \multirow[t]{8}{*}{119} & \multirow[t]{8}{*}{ Resina Guajac } & 12.43 & Vanillin methylether (Veratric aldehyde) & $166(166)$ & \multirow{8}{*}{$\begin{array}{l}\text { Complex mixture of guaiacum resin } \\
\text { (Guaiacum officinale L./G. Sanctum L.) } \\
\text { and a fatty fraction. } \\
\text { (Similar composition of sample LS 193) }\end{array}$} \\
\hline & & 12.61 & Propenyl guaiacol & $164(164)$ & \\
\hline & & 18.26 & Veratric acid ME & $196(196)$ & \\
\hline & & 22.35 & Myristic acid ME & $242(74)$ & \\
\hline & & 23.78 & Palmitic acid ME & $270(74)$ & \\
\hline & & 30.04 & Guaiaretic acid (galbulin) & $356(356)$ & \\
\hline & & 31.89 & Benzene, 4-dimethoxymethyl-1,2-dimethoxy & $212(181)$ & \\
\hline & & 33.64 & Guaiaconic acid (galgravin) & $372(206)$ & \\
\hline \multirow[t]{12}{*}{142} & \multirow[t]{12}{*}{ Babam odintalg } & 7.79 & Hydrocinnamic aldehyde & $134(91)$ & \multirow{12}{*}{$\begin{array}{l}\text { Complex mixture of balsamic compounds, } \\
\text { terpenic compounds and fatty acids. }\end{array}$} \\
\hline & & 9.85 & Cadinene & $204(161)$ & \\
\hline & & 11.17 & Cinnamic acid ME & $162(131)$ & \\
\hline & & 12.35 & Vanillin methyl ether (veratric aldehyde) & $166(166)$ & \\
\hline & & 12.56 & Patchoulol & $222(41)$ & \\
\hline & & 13.69 & Veratric acid ME & $196(196)$ & \\
\hline & & 14.76 & Methylmethoxy cinnamate & $222(222)$ & \\
\hline & & 18.22 & Palmitic acid ME & $270(74)$ & \\
\hline & & 21.83 & Oleic acid ME & $296(55)$ & \\
\hline & & 22.33 & Stearic acid ME & $298(74)$ & \\
\hline & & 26.07 & Dehydroabietic acid ME & $314(239)$ & \\
\hline & & 28.21 & Junicedric acid & 336 & \\
\hline \multirow[t]{11}{*}{171} & \multirow[t]{11}{*}{ Unlabelled } & 10.17 & Decanoic acid ME & $186(74)$ & \multirow{11}{*}{$\begin{array}{l}\text { Very complex mixture of fatty acids, } \\
\text { diterpenic resins (neutral labdanic } \\
\text { compounds in pine resin and larch } \\
\text { turpentine), and pentacyclic triterpene } \\
\text { compounds (amyrins and lupeol). }\end{array}$} \\
\hline & & 11.86 & Dodecanoic Acid ME & $214(74)$ & \\
\hline & & 17.49 & Cinnamic acid ME & $162(131)$ & \\
\hline & & 21.31 & Epimanool & $290(137)$ & \\
\hline & & 23.67 & Larixol acetate & $333(153)$ & \\
\hline & & 25.02 & Larixol & $306(69)$ & \\
\hline & & 25.42 & Isopimaric acid ME & $316(241)$ & \\
\hline & & 26.69 & Dehydroabietic acid ME & 314 (239) & \\
\hline & & 39.13 & Beta-amyrin & $426(218)$ & \\
\hline & & 40.25 & Alpha-amyrin & $426(218)$ & \\
\hline & & 41.51 & Lupeol acetate & $468(43)$ & \\
\hline \multirow[t]{6}{*}{174} & \multirow[t]{6}{*}{ Balsam S.Ton } & 7.86 & Camphor & $152(95)$ & \multirow{6}{*}{$\begin{array}{l}\text { Fairly complex mixtures of balsamic } \\
\text { compounds (monoterpenes and } \\
\text { sesquiterpene of essential oils). }\end{array}$} \\
\hline & & 8.24 & Borneol & $154(95)$ & \\
\hline & & 8.61 & Benzyl alcohol & $108(79)$ & \\
\hline & & 8.81 & Cedrol & $222(95)$ & \\
\hline & & 11.57 & Geranic acid ME & $182(69)$ & \\
\hline & & 12.65 & Endoborneol & $154(95)$ & \\
\hline
\end{tabular}


Table 2 (continued)

\begin{tabular}{|c|c|c|c|c|c|}
\hline Sample \# & Sample name & $\begin{array}{l}\mathrm{RT} \\
(\min )\end{array}$ & Main compounds detected & $\begin{array}{l}\mathrm{m} / \mathrm{z} \text { values of } \mathrm{M}+ \\
\text { (most abundant ion) }\end{array}$ & Considerations \\
\hline \multirow[t]{11}{*}{193} & \multirow[t]{11}{*}{ Guaiaco resin } & 9.09 & p-Ethylguaiacol & $152(137)$ & \multirow{11}{*}{$\begin{array}{l}\text { Complex mixture of guaiacum resin } \\
\text { (Guaiacum officinale L./G. Sanctum L.) } \\
\text { and a fatty fraction } \\
\text { (Similar composition of sample LS 119) }\end{array}$} \\
\hline & & 12.37 & Vanillin methyl ether (veratric aldehyde) & $166(166)$ & \\
\hline & & 12.55 & Propenyl guaiacol & $164(164)$ & \\
\hline & & 13.71 & Dimethoxy benzoic acid ME & $196(165)$ & \\
\hline & & 18.23 & Palmitic acid ME & $270(74)$ & \\
\hline & & 18.97 & Veratric acid ME & $196(196)$ & \\
\hline & & 21.84 & Oleic acid ME & $296(55)$ & \\
\hline & & 22.34 & Stearic acid ME & $298(74)$ & \\
\hline & & 29.99 & Guaiaretic acid (galbulin) & $356(356)$ & \\
\hline & & 31.21 & Benzene, 4-dimethoxymethyl-1,2-dimethoxy & $212(181)$ & \\
\hline & & 33.31 & Guaiaconic acid (galgravin) & $372(206)$ & \\
\hline \multirow[t]{14}{*}{223} & \multirow[t]{14}{*}{ Ladon } & 9.85 & Hydrocinnamic ME & $164(104)$ & \multirow{14}{*}{$\begin{array}{l}\text { Extremely complex mixture containing the } \\
\text { resin "ladano", other diterpenes from } \\
\text { larch and fatty acids. }\end{array}$} \\
\hline & & 11.46 & Cinnamic acid ME & $162(131)$ & \\
\hline & & 11.30 & Dimethoxybenzaldehyde & & \\
\hline & & 13.43 & Azelaic acid ME & $216(152)$ & \\
\hline & & 14.00 & Benzoic acid ME & $136(105)$ & \\
\hline & & 15.53 & Myristic acid ME & $242(74)$ & \\
\hline & & 16.93 & Pentadecanoic acid ME & $256(74)$ & \\
\hline & & 18.77 & Palmitic acid ME & $270(74)$ & \\
\hline & & 20.54 & Manoyloxide & $290(275)$ & \\
\hline & & 22.15 & Sclareolide & $250(43)$ & \\
\hline & & 22.85 & Stearic acid ME & $298(74)$ & \\
\hline & & 24.28 & Larixol & $306(69)$ & \\
\hline & & 26.30 & Arachidic acid ME & $326(74)$ & \\
\hline & & 26.52 & Dihydromanoyloxide & $292(245)$ & \\
\hline \multirow[t]{15}{*}{232} & \multirow[t]{15}{*}{ Resin scamon } & 9.56 & Corynanthine & $354(353)$ & \multirow{15}{*}{$\begin{array}{l}\text { Extremely complex mixtures of scammony } \\
\text { resin, fatty acids (vegetable oil with } \\
\text { unsaturation) and fatty alcohols }\end{array}$} \\
\hline & & 9.94 & Rhamnopyranosyl & $164(90)$ & \\
\hline & & 10.46 & Capric acid ME & $186(74)$ & \\
\hline & & 12.50 & Hydroquinone & $110(110)$ & \\
\hline & & 14.53 & Glucopyranoside & $194(60)$ & \\
\hline & & 15.53 & Myristic acid ME & $242(74)$ & \\
\hline & & 16.93 & Pentadecanoic acid ME & $256(74)$ & \\
\hline & & 16.97 & Hexadecanol & $242(55)$ & \\
\hline & & 17.27 & Myristic alcohol & $214(43)$ & \\
\hline & & 17.97 & Dimethoxy-cinnamic acid ME & $222(222)$ & \\
\hline & & 18.76 & Palmitic acid ME & $270(74)$ & \\
\hline & & 22.35 & Oleic acid ME & $296(55)$ & \\
\hline & & 22.77 & Linoleic acid & $294(67)$ & \\
\hline & & 25.40 & Tridecanoic acid ME & $228(74)$ & \\
\hline & & 26.50 & Dehydroabietic acid ME & $314(239)$ & \\
\hline
\end{tabular}

More precisely, GC-MS analyses revealed the presence of aromatic methyl esters (cinnamic acid and oxidised benzoic acid, marked with numbers 3 and 2 respectively in Fig. 2), with their corresponding aromatic acids, methoxy-benzaldehyde (peak 1), toluene (peak 6) and fatty acid (peak 9).

Cinnamic acid and benzoic acid are the main components of two phenolic resins: benzoin resin (Styrax genus) or storax/ styrax resin (Liquidambar genus).
The term styrax has generated a fairly frequent nomenclatural confusion in resin terminology, so much so that Liquidambar gums (Hamamelidaceae) are often marketed as benzoin but should not be considered such from a botanical and chemical point of view (Hovaneissian et al. 2006; Langenheim 2013).

The presence of vanillin methyl ether (peak 4) was also revealed, which is crucial for the distinction between benzoin 


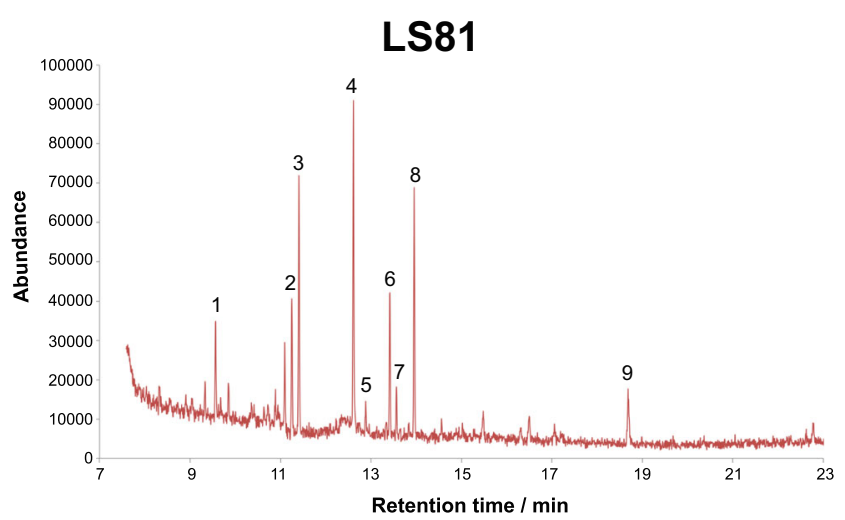

Fig. 2 TIC chromatogram of sample LS81 after transesterification and GC-MS analysis. Peak 1 = benzaldehyde, 4-methoxy; 2 = benzoic acid, 4-methoxy-diME; 3 = cinnamic acid ME; 4 = vanillin methyl ether (veratric aldehyde) $5=$ terephthalic acid diME; $6=$ toluene; $7=$ benzene, 4-dimethoxymethyl-1, 2-dimethoxy; $8=$ veratric acid ME; $9=$ tridecanoic acid ME

resin (in which it is present) and storax resin (in which it is absent) (Modugno et al. 2006). Furthermore, by analysing a historical drug, we must take into account the possible degradation of the compounds. In fact, vanillin, being an aldehyde, is not a very stable compound by nature, and it easily oxidises in its corresponding acid: veratric acid (also detected as methyl ester, marked with peak number 8).

Hovaneissian et al. (2008) report that the storax resin obtained from the Turkish species (Liquidambar) contains isovanillin in very smaller amounts than cinnamic acid and benzoic acid. As reported in literature, methoxybenzaldehyde (1) was detected in ancient samples of benzoin resin and not in those of storax resin (Modugno et al. 2006). Castel et al. (2006) find the presence of toluene as a volatile constituent of the benzoin resin. In this case, the sample LS81 was in a sealed jar, so volatile compounds such as toluene (peak 6) may not have evaporated.

In light of the results obtained by analytical technique, it can be stated that the sample under examination is indeed benzoin resin and not styrax resin.

Benzoin resin, in fact, is a balsamic resin of rather hard consistency whose main components are not terpenes but aromatic esters (benzoic acid and cinnamic acid) with their corresponding aromatic acids. The amount of these compounds is very variable and depends on the resin species from which they are obtained. It comes from the Styrax genus, from the Stryraceae family (Mills and White 1994; Neamsuvan et al. 2012). Moreover, the label quoted the name "benzoin" and the hardness of the sample immediately suggest a connection with the benzoin resin.

Benzoin resin was traditionally used in medicine, cosmetics, perfumery and ritual ceremonies along with myrrh (Commiphora myrrha) or olibanum (Boswellia thurifera; Boswellia sacra) for its characteristic odoriferous properties. In the Mediterranean region, it was already known by the
Ancient Greeks: It is in fact mentioned by Herodotus (fifth century AD) and Theophrastus (fourth and third century AD) and is recommended by Hippocrates (fifth and fourth century AD) as a remedy (Langenheim 2013). However, the first report which unequivocally refers to this resin comes from the fourteenth century Arab traveller Ibn Batuta. It was suggested that the Arabic name luban djawi (frankincense of Java) was later changed to banjawi to finally give benjoin or benzoin. The only representative of the Styracaceae in the Mediterranean and native to Cyprus is Styrax officinalis (Meikle 1977/1985), the source of solid storax. Interestingly, both dioscorides and Pluny in writing about styrax mentioned that the product comes not only from places now in southeastern Turkey, western Syria or Lebanon but also from Cyprus and Crete (Lardos et al. 2011).

Table 3 summarises (some of) the uses and pharmacological functions of benzoin resin as a medicament, ranging from anti-inflammatory agent to filling for a skull fracture.

In the artistic field, benzoin resin has been used since the sixteenth century as a painting coating (especially for wooden supports). Thanks to its film-forming properties, it was used both alone and in a mixture with shellac to give better polish and smoothness to the polishing effect (Beninatto and De Lucchi 2016).

\section{LS119 Resina Guajac and LS193 guaiacol resin}

Reddish-brown small fragments, partially translucent, and slightly sticky, constituted these samples.

The preliminary study conducted by FT-IR spectroscopy showed very similar IR spectra. After analysing the samples via GC-MS, we had further confirmation of the similarity between the samples and for this reason, we decided to show only one of the chromatograms (reported in Fig. 3).

Among the compounds identified by GC-MS, the characteristic components of guaiac resin have been detected: guaiacol derivatives (marked with * and number 2), vanillin (peak 1), guaiaretic acid (called also galbulin, peak number 7) and guaiaconic acid (galgravin, peak number 9), whose structures are shown in Fig. 4.

It is possible to state that these two pharmaceutical remedies, contained in different jars, mainly contain guaiacum resin. As reported in the literature, the resin extract from (Guaiacum officinale L./G. Sanctum L.) (Fam. Zygophyllaceae, a plant native to Central America and the Caribbean, mainly from Costa Rica, Jamaica, Dominican Republic, Cuba and Brazil) is a complex mixture containing approximately $70 \%$ alpha- and beta-guaiaconic acids, $10 \%$ guaiaretic acid and $15 \%$ guaiac beta-resin; additionally, guaiac yellow and vanillin are present (Haworth et al. 1934).

Furthermore, the name reported on their labels permits to hypothesise that these compounds may derive from the guaiacum, a Zygophyllaceae timber (Guaiacum sanctum L. or 


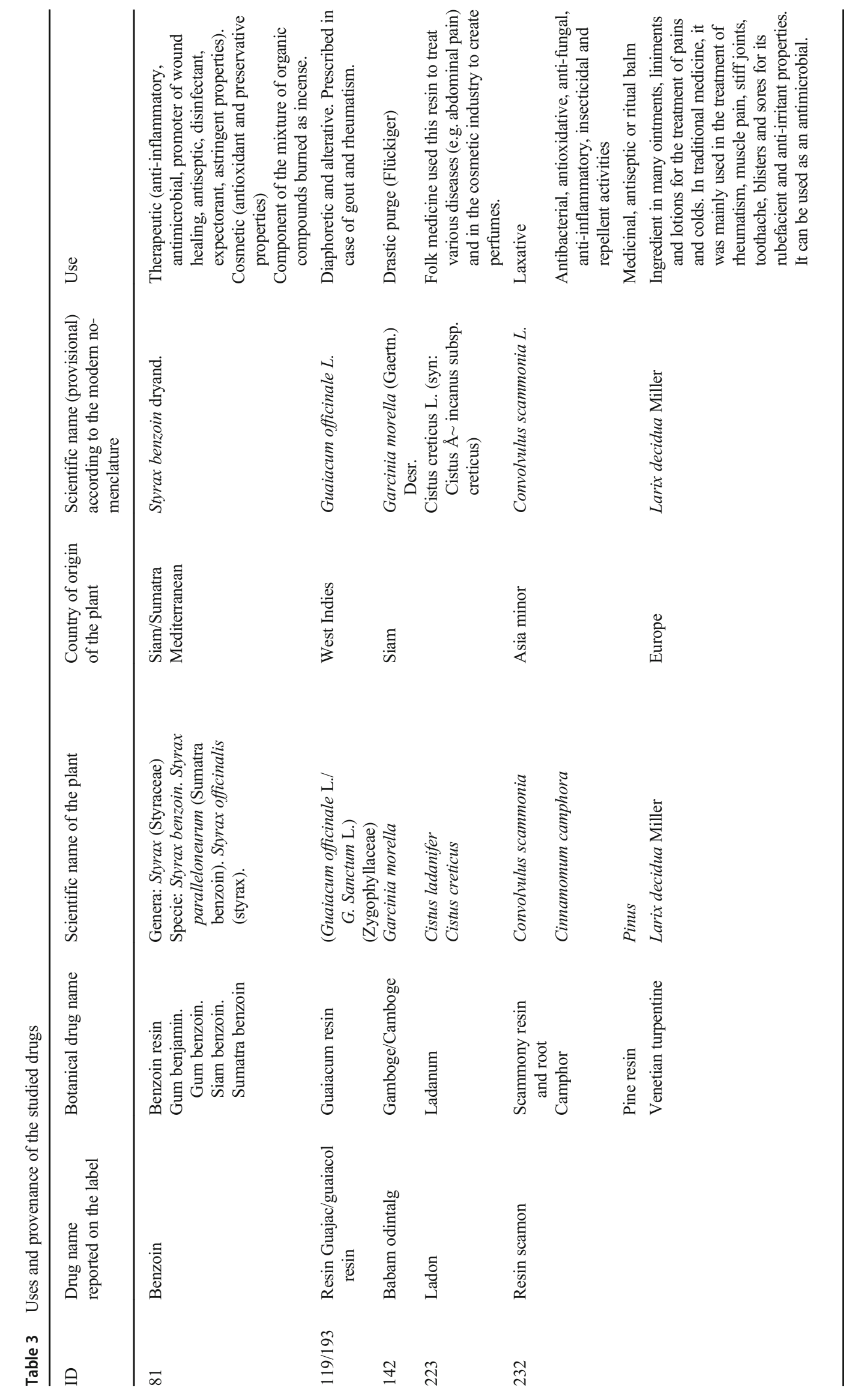




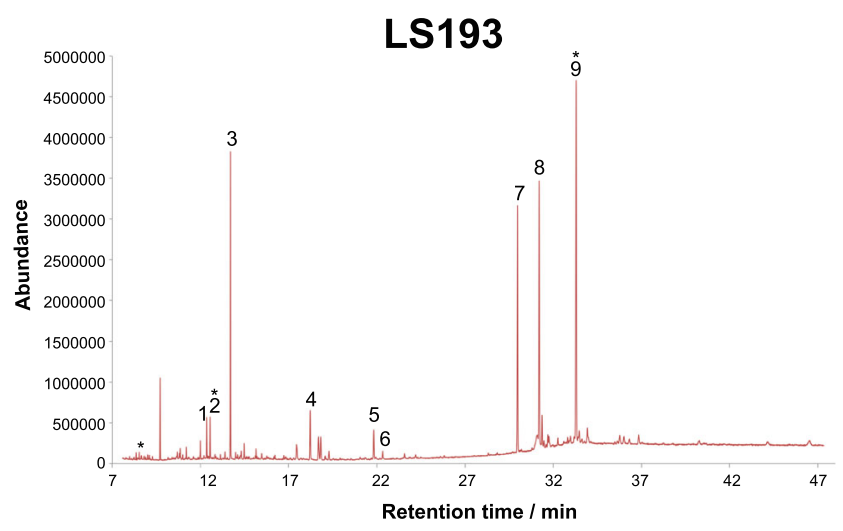

Fig. 3 TIC chromatogram of sample LS 193 after transesterification and GC-MS analysis. Peak $*=$ p-ethylguaiacol; $1=$ vanillin methyl ether (veratric aldehyde); 2 = propenyl guaiacol; $3=$ dimethoxy benzoic acid ME; 4 = palmitic acid ME; $5=$ oleic acid ME; $6=$ stearic acid ME; $7=$ guaiaretic acid (galbulin); $8=$ benezene,1,2-dimethoxy; $9=$ guaiaconic acid (galgravin)

G. officinale $L$.), whose resin is generally called gum guaiac or resin Guajac (Kratochvil et al. 1971; Medeiros and De Albuquerque 2012; Brandão et al. 2008).

The presence of some fatty acids, in particular palmitic acid, oleic acid and stearic acid (peaks marked with numbers 4, 5 and 6 respectively), can be explained by their use as a vehicle for taking the remedy: Indeed, a vegetable oil might have been employed. The presence in a high amount of oleic acid suggests that the oxidation of the organic material did not completely occur; this may be related to the closure of the jars: It was probably so well sealed that slowed the oxidation processes.

About the use of guaiacum resin, the historical research reports many medical and pharmacological applications, for instance, its use in the form of a decoction to treat chronic gouty affections (Munger 1949; Corp and Pendry 2013) and rheumatism (Kratochvil et al. 1971). In addition, guaiac wood (lignum sanctum) has also been used to treat diseases, for example syphilis (Vargová et al. 2019).

\section{Samples LS 171 unlabelled}

Figure 5 depicts the chromatogram obtained from sample LS171 after transesterification and GC-MS analysis.

\section{LS171}

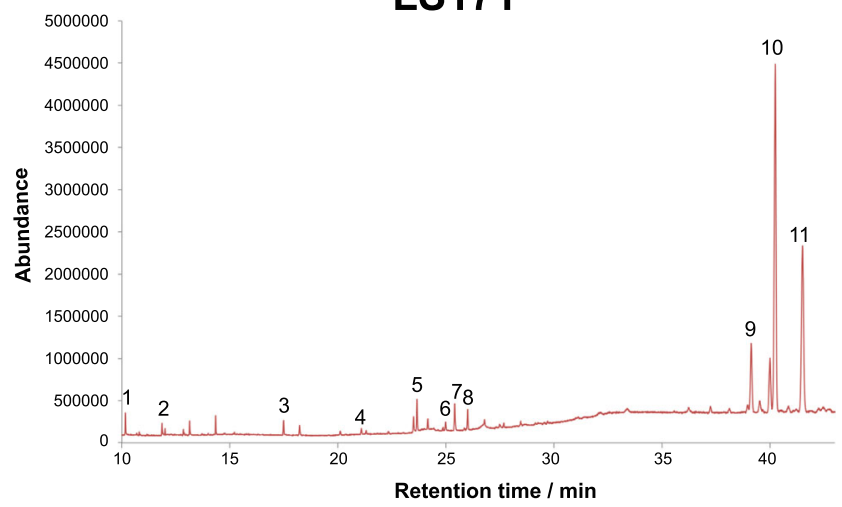

Fig. 5 TIC chromatogram of LS171 sample after transesterification and GC-MS analysis. Peak 1 = decanoic acid ME; 2 = dodecanoic acid ME; 3 = cinnamic acid ME; $4=$ epimanool; $5=$ larixol acetate; $6=$ larixol; $7=$ isopimaric acid ME; 8 = dehydroabietic ME; 9 = beta-amyrin; $10=$ lupeol acetate; 11 = alpha-amyrin

GC-MS evidenced a high heterogeneity in the composition of the pharmaceutical preparation, although the identified compounds mainly consist of materials of vegetable origin.

The presence of monocarboxylic acids, i.e. decanoic and dodecanoic acids (peaks 1 and 2), is visible in the first part of the chromatogram (lower molecular weights).

During the identification by GC-MS, the presence of characteristic diterpene biomarkers made it possible to evaluate the presence of pine resin. In fact, the simultaneous presence of neutral labdane compounds or rather epimanool (peak 4), larixol acetate (peak 5) and larixol (peak 6) (whose structures are reported in Fig. 6) emphasizes that material contains a semi-liquid resin extracted from Larix decidua, in particular Venice turpentine (also known as larch turpentine) (Mills and White 1994; Mazzei et al. 2020).

Furthermore, isopimaric acid (peak 7) and dehydroabietic acid (peak 8) were detected. This evidence permits to advance the hypothesis that the material contains a resin obtained by distilling a piece of wood from the Pinaceae family (Mills and White 1994). Dehydroabietic acid is present in fresh resins, but its concentration tends to increase over time. In ancient resins, in fact, the volatile fraction decreases while the percentage of diterpenes increases: Dehydroabietic acid is present in large quantities in ancient resins as a<smiles>CCc1ccc(O)c(OC)c1</smiles><smiles>C/C=C\c1ccc(OC)c(O)c1</smiles>

\section{p-ethylguaiacol}

\section{Propenyl guaiacol}<smiles>COc1ccc([C@H]2c3cc(OC)c(OC)cc3C[C@@H](C)[C@H]2C)cc1OC</smiles>

Galbulin<smiles>COc1ccc([C@@H]2O[C@@H](c3ccc(OC)c(OC)c3)C(C)C2C)cc1OC</smiles>

Guaiaconic acid

Fig. 4 Structures of main compounds present in Guajacum resin 
degradation product of abietadienic acids, easily degradable due to a conjugated double bond (Mills and White 1994) marker of a Pinaceae resin as well, even if aged.

Furthermore, pentacyclic triterpenes were detected as well, namely alpha /beta-amyrin (peaks 11 and 9 respectively) and lupeol acetate (peak 10 of Fig. 6). Moreover, the experimental evidence combined with historical research and the botanical composition has allowed us to formulate a hypothesis regarding the co-presence of these triterpene compounds: It could be the exudate of a plant from South America, most likely a copal (Merali et al. 2018). This hypothesis can be sustained by the fact that friars controlled the trade route with the West Indies (da Cruz Albino et al. 2020).

Taking into account the results obtained from this crossinvestigation, it can be hypothesised that the LS171 sample is a mixture of saturated fatty acids which act as carriers and/or reduce the viscosity of an oleoresin from the larch (Venetian turpentine), a pine resin (Pinaceae family) and an exudate from a plant of South American origin.

This complex mixture could have been used as an ointment with an anti-inflammatory purpose since the steroid structures often determine this property (Figueroa-Suárez et al. 2019). Moreover, the cinnamic skeleton is interesting for the development of new antimicrobials; however, its antimicrobial mechanism of action is little known (Guzman 2014).

\section{LS232 resin scamon and LS223 Ladon}

GC-MS results highlighted extremely complex mixtures. The sample LS232 seems to be a mixture of scammony resin, fatty acids (vegetable oil with unsaturation) and fatty alcohols (all compounds identified are listed in Table 2).

On the other hand, LS223 sample is a very complex mixture of "ladano" resin, a characteristic marker of Venetian turpentine (larixol), and fatty acids.

GC-MS analyses revealed the characteristic compounds of scammony resin (peaks number 2 and 5). According to the literature, rhamnopyranosyl (peak 2) and glucopyranoside (peak 5) appear to be the constituents of scammonic acid, a glucosidic acid which is one of the main components of scammony resin (Fig. 7) (Noda et al. 1990).

Moreover, the name reported on the label "resin scamon" may refer to the scammony resin, also called resin scammonium, an extract of the root of Convolvulus scammonia L., a plant original of the eastern Mediterranean and some Near East places, such as Crimea, Caucasus, Turkey, Syria, Greece and Iran. Historically this plant was known by Hippocrates (around $400 \mathrm{BC}$ ) and Theophrastus (around $300 \mathrm{BC}$ ) for its purgative and cholagogic action (Langenheim 2013; De Vos 2010).

As mentioned above, fatty acids (in this case, capric acid (peak 3), pentadecanoic acid, myristic acid, palmitic acid (peak 6), oleic acid (peak 8), linoleic acid, dimethyl-
Fig. 6 Structures of the main compounds present in sample LS171<smiles>C=C[C@H](O)CCCC1C(=C)CCC2C(C)(C)CCCC12C</smiles>

Epimanool<smiles>C=CC(C)CCC1C(=C)CC(O)[C@H]2[C@@H](C)CCCC12C</smiles>

Larixol<smiles>C=C(C)OC(=C)CCC1CC(=O)OCC12CCCCC2(C)C</smiles>

Larixol acetate

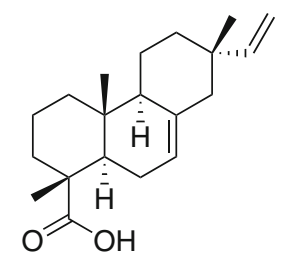

Isopimaric acid

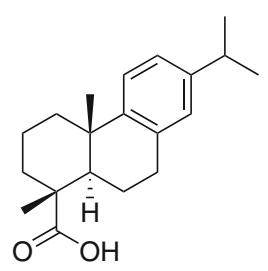

Dehydroabietic acid

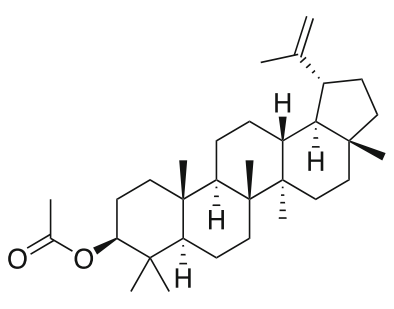

Lupeol acetate

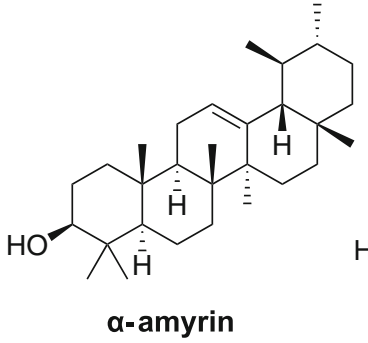

a-amyrin

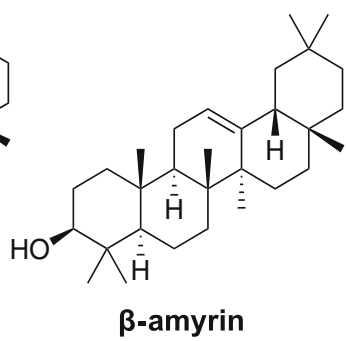




\section{LS232}

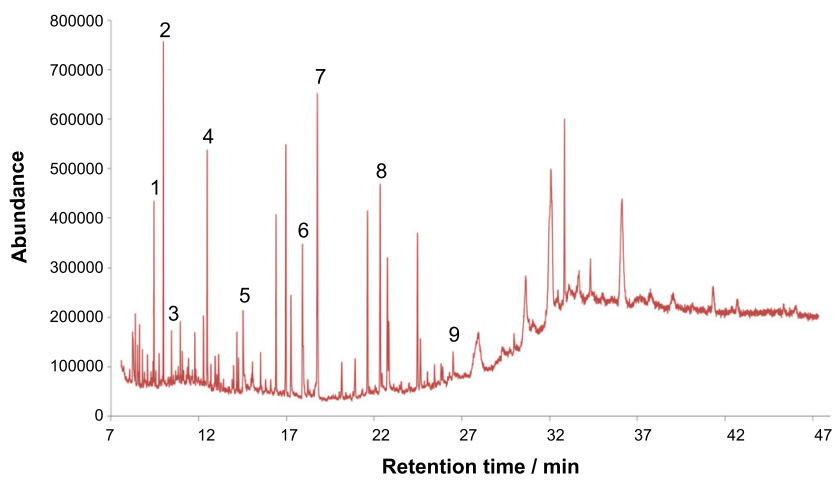

Fig. 7 TIC chromatogram of LS232 sample after transesterification and GC-MS analysis. Peak 1 = corynathin; 2 = rhamnopyranosyl; 3 = capric acid ME; 4 = hydroquinone; 5 = glucopyranoside; $6=$ dimethoxycinnamic acid ME; $7=$ palmitic acid ME; $8=$ oleic acid ME; $9=$ dehydroabietic acid $\mathrm{ME}$

undecanoic acid and tridecanoic acid were detected) are probably present as carries and as agent reducing the viscosity of the extract. Fatty alcohols (such as hexadecanol and myristic alcohol) could be used as emollients, emulsifiers or thickening agents. Corynathin (peak 1) is a typical alkaloid of Amsonia Elliptica brevifolia (Sauerwein and Shimimoura 1990); the hydroquinone (peak 4) (as cinnamic acid) instead is a phenol normally present in plant families; for this reason, we cannot consider it a characteristic biomarker. Finally, dehydroabietic acid (peak 9) can be present as a maker of pine resin or as a degradation product of abietadiene acids.

The compounds identified within the LS223 sample by GC-MS analysis are shown in Table 2.

Figure 8 depicts the chromatogram of sample LS223, sclareolide and manoyloxide (marked with $1^{*}$ and $2{ }^{*}$ ) which are the main components of resin ladan, an exudate of Cistus creticus, a plant that grows in Greece, more precisely on the island of Crete (Demetzos et al. 1994). From historical research, it seems that the name "Ladon" written on the LS223

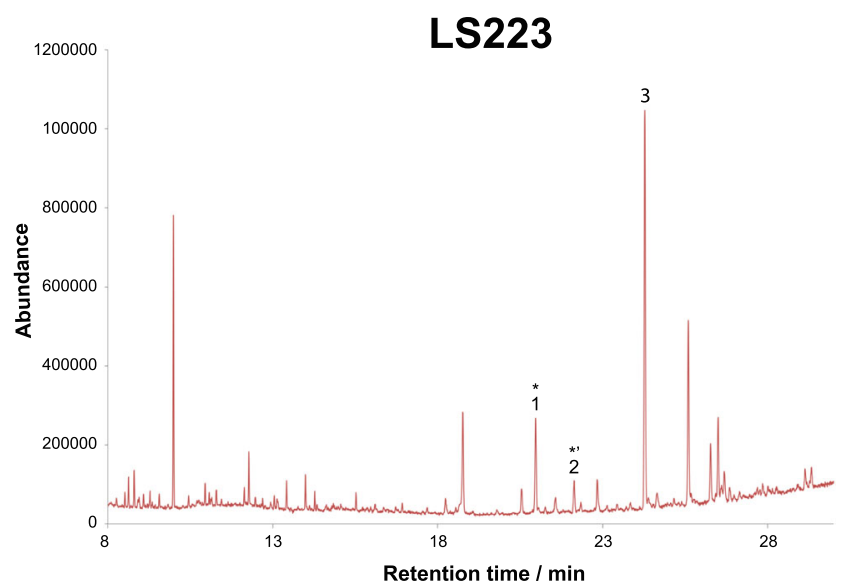

Fig. 8 TIC chromatogram of LS223 sample after transesterification and GC-MS analysis. Peak $1{ }^{*}=$ sclareolide; $2^{* \prime}=$ manoyloxide; $3=$ larixol sample label may also refer to "ladan" resin. Folk medicine used this resin to treat various diseases (Demetzos et al. 1994) - e.g. abdominal pain (Rivera et al. 2019) — and in the cosmetic industry to create perfumes (Mackonochie and Heinrich 2019). From the Greeks, many of its properties were attributed by the association of the name, Ladon, to the mythological account. In Greek mythology, this was the name of the hundred-headed dragon in charge of guarding the garden of the Hesperides with the help of some nymphs (Graves 1992). All the Cistus species are frequently used in many traditional medicines for their antimicrobial, antitumor, antiviral and anti-inflammatory properties (Bouamama et al. 2006).

Larixol (peak 3) and fatty acids (myristic acid, pentadecanoic acid, palmitic acid, stearic acid and arachidic acid) were also identified. The first is a neutral labdane diterpene, a characteristic marker of Venetian turpentine.

\section{LS174 Balsam S.Ton and LS142 Babam odintalg}

In this section, aromatic substances are discussed.

GC-MS analyses on LS174 sample revealed a fairly complex mixture of balsamic compounds (monoterpenes and sesquiterpene of essential oils), whose chromatogram is shown in Fig. 9. As reported in Table 2, monoterpenes (camphor, borneol, endoborneol), benzyl alcohol, cedrol and geranic acid were detected.

As reported in the literature, cedrol (peak 4) could be detected in the essential oil of conifers, especially in Cupressaceae and Juniperaceae genera (Hosseinihashemi et al. 2017; Fadel et al. 2019). Camphor (peak 1), borneol (peak 2) and endoborneol (peak 6) are bicyclic monoterpenes: The first one is obtained by steam distillation from the wood of the camphor tree, the Cinnamomum camphora. This is one of the oldest herbal medicines used as a traditional medicine, owning a wide range of biological functions, including

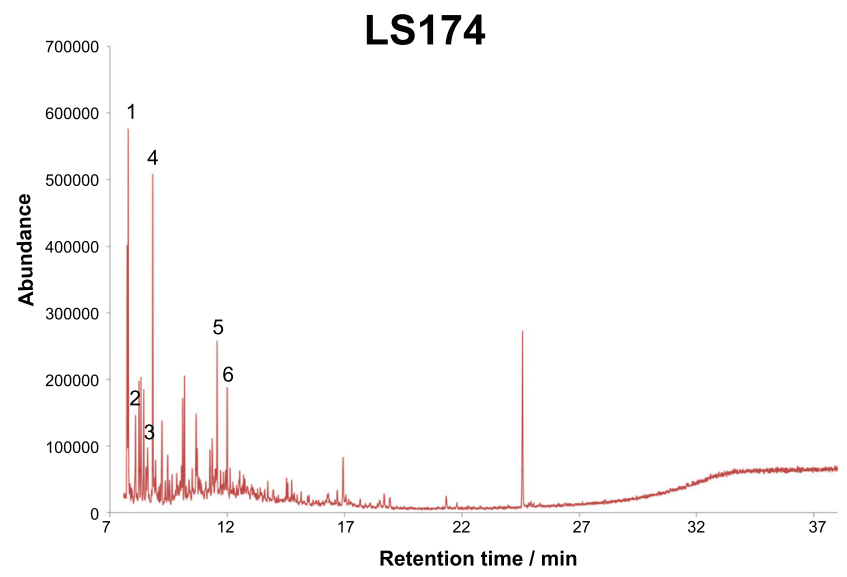

Fig. 9 TIC chromatogram of LS174 sample after transesterification and GC-MS analysis. Peak 1 = camphor; 2 = borneol; 3 = benzyl alcohol; 4 = cedrol (cedrolie); 5 = geranic acid ME; 6 = endoborneol 
antibacterial, antioxidative, anti-fungal, anti-inflammatory, insecticidal and repellent activities (Chen et al. 2020). The other monoterpenes are normally present in essential oils with benzyl alcohol (peak 3) and geranic acid (peak 5) (Beninatto and De Lucchi 2016).

The compounds identified within the LS142 sample are displayed in Table 2. This is a complex mixture of balsamic compounds, terpene compounds and fatty acids.

Cadinene (peak 1) and junicedric acid (peak 11) methyl ester could be present not only in the juniper essential oil (Juniperus oxycedrus L.) (Duane and Thomas 1991), but also in the Araucaria araucana, a plant of Argentine origin that was used for the treatment of bruises and ulcers and as a wound-healing agent (Fig. 10) (Shahzad Aslam et al. 2013).

Methyl esters of phenol-carboxylic acids (benzoic and cinnamic acid (peak 2) and their derivatives identified can be interpreted as constituents of many species of the plant kingdom (plants, dried fruit). Moreover, patchoulol (peak 4) was detected. As reported in literature, it is one of the main compounds of patchouli essential oil (Verma et al. 2019; Kusuma and Mahfud 2017). Also in this case, fatty acids, such as palmitic, oleic and stearic acids ME (peaks 7, 8, 9 respectively), were detected; in all probability, they have the function of carriers. Dehydroabietic acid methyl ester was also identified (peak 10). As reported above, it is a fresh resin constituent and in ancient resins, it can be present as a degradation product of abietadienic acids, easily degradable due to a conjugated double bond (Mills and White 1994).

\section{Uses and provenance of the studied drugs}

This section presents a summary table that affects some of the samples studied and the connection between the composition of the drug and the names reported on the jars.

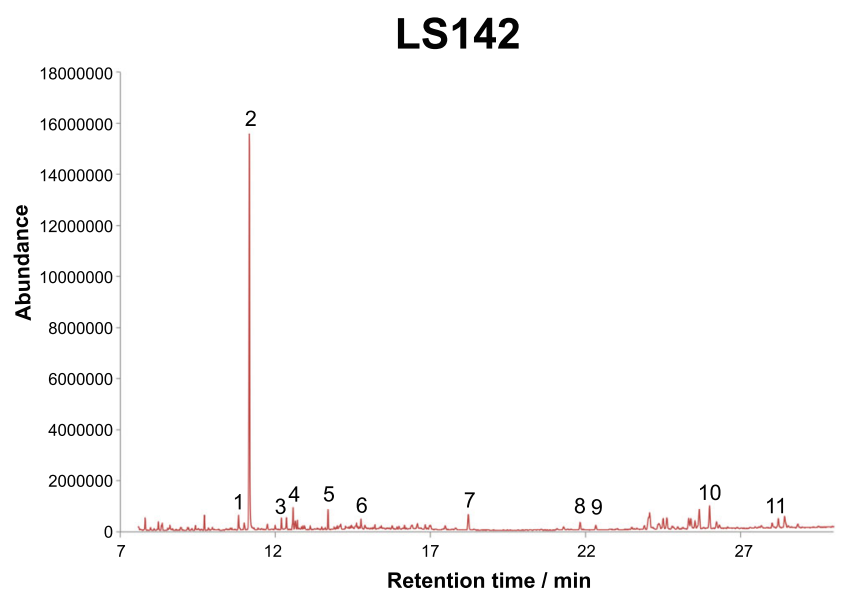

Fig. 10 TIC chromatogram of LS142 sample after transesterification and GC-MS analysis. Peak 1 = cadinene; $2=$ cinnamic acid ME; $3=$ vanillin methyl ether (veratric aldehyde); $4=$ patchoulol; $5=$ veratric acid ME; $6=$ methylmethoxy cinnamate; $7=$ palmitic acid ME; $8=$ oleic acid ME; $9=$ stearic acid ME; $10=$ dehydroabietic acid ME; $11=$ junicedric acid ME
In general, it can be said that many resins and oleoresins have antiseptic, anti-inflammatory and antibacterial properties and are used in cosmetics or as perfumes or in incense (Mackonochie and Heinrich 2019).

\section{Conclusions and further perspectives}

The chemical investigation by GC-MS has successfully identified the organic materials preserved in selected historical remedies and pharmaceutical formulations from the Spezieria di Santa Maria della Scala in Rome. They resulted to be complex mixtures containing several vegetal resins, balsams and fatty acids.

Natural resins have been used as ointments with anti-inflammatory, antiseptic and antibacterial properties. These historical drugs were used in cosmetics, perfumes and incenses. Many of them were exudates of plants imported and it is assumed that they could have been used in a mixture according to ancient recipes. The phenol-carboxylic acids identified (benzoic and cinnamic acid and their derivatives) can be interpreted as constituents of many species of the plant kingdom (plants, dried fruit). The presence of some fatty acids (e.g. lauric acid, capric acid, palmitic acid, oleic acid, stearic acid) may be explained by the use of oils as carriers to take the remedy and/or to reduce the viscosity of the conditioner and as a base for mixing more "exotic" ingredients.

The analytical challenge for the study of the chemical composition of the remedies, combined with historical and botanical research, allowed to formulate compositional hypotheses of ancient medicines. The chemical investigation of the substances preserved in ancient "spezieries and apothecaries" is helping to substantiate the presence and provenance of many pharmaceutical drugs of ancient origin that were still in use in the Middle Ages and the Modern Era, as we have been able to verify in this study. Several of the drugs discussed here are complex formulations that include organic substances from America (guaiacum resin), Near East (scammony resin) or products of great importance in Islamic medicine, such as benzoin. The physicochemical identification, on the other hand, of aromatic compounds associated with these complex formulations, confirms the importance that fragrance had in the preparation of compounds that had to be ingested, whether or not they had other therapeutic properties.

This study of historical drugs is important also to deepen the knowledge of the practices handed down by apothecaries in the past, and also to reconstruct historical recipes that can inspire new dermatological, cosmetic, hygienic and current curative products, as occurs in laboratories of great recognition today, such as Aboca Coop. Agricola in Italy or L'Oreal in France.

Historical sources and analytical results allowed to confirm and provide a wide database which helps to identify trends in 
the continuous use of pharmaceutical drugs and medicinal practices from ancient cultures in Mediaeval, Modern and Baroque Europe. Even more, the deities, myths and beliefs of antiquity like the one that has been commented for the case of Ladon (sample L223), which substantiated the formula of many of these drugs, on which their therapeutic efficacy was often based, also found their way into the mediaeval and modern European pharmacopoeias (Junius 1985), used by the friars of the Roman Spezieria di Santa Maria della Scala. In the Middle Ages, a distinction began to be made between the more highly cultured or official medical knowledge practised by doctors and apothecaries and the popular wisdom handed down to modern times through oral tradition and ethnobotany and mainly imparted by women, usually associated with the practice of magic and sorcery (Maderna 2012). Despite all this, until recently, the history of the drug as a crucial part in the history of religions and comparative cultural anthropology was a pending chapter (Escohotado 1999). And yet, any of these plant substances, analysed from both disciplinary areas, allows to deepen the worldview of societies and cultures over time, and consequently understand highly precise and significant ritual, social practices and aspects of daily life. This category includes most of the resins considered in this research, such as resin scamon (L232), as it shows the iatrosophia $(\llcorner\alpha \tau \rho \circ \sigma o ́ \phi \iota \alpha)$, literally medical wisdom, and other substances from the plant kingdom, such as flowers, also present in Santa Maria della Scala, Rome, and the object of future studies.

The analytical information gathered in this study, thus, is an important resource for the knowledge of historical drug formulations and answers questions that, until now and to the best of our knowledge, had remained partially unresolved. In addition, this study will implement some of the projects carried out by the universities involved in this research, dedicated to the dissemination of the importance of knowing in a tangible and intangible way the ancient cultures and their historical sites (Lobovikov Katz et al. 2014; Vázquez de Ágredos Pascual et al. 2019).

Acknowledgments Authors would express their gratitude to Valetino Mercati, President of Aboca Coop. Agricola (Sansepolcro, Italy) for the financial support of the Research Project Antichi minerali nell'arte degli speziali di "De Medicamentaria Officina" di Santa Maria della Scala, Roma. Indagini Chimico-Fisiche e Studio Storico-Culturale (20172019), and of the Research Project Droga e colore: studio di materie prime, formulazioni e processi produttivi dall'Antichitá al Mondo Attuale (2020-2021). Also, they would express their gratitude to the Consellería d'Innovació, Universitats, Ciència i Societat Digital, Generalitat Valenciana, for the financial support of the Research Project Roma Hispana. Inteligencia Artificial y Nuevas Tecnologías aplicadas al estudio, la musealización y la puesta en valor de Patrimonio Cultural español en Roma: la spezieria de Santa Maria della Scala, 2020-2021 (AICO/083).
Funding Open access funding provided by Università Ca' Foscari Venezia within the CRUI-CARE Agreement. For this research, the authors received financial support from Valentino Mercati, President of Aboca (Sansepolcro, Italy).

Open Access This article is licensed under a Creative Commons Attribution 4.0 International License, which permits use, sharing, adaptation, distribution and reproduction in any medium or format, as long as you give appropriate credit to the original author(s) and the source, provide a link to the Creative Commons licence, and indicate if changes were made. The images or other third party material in this article are included in the article's Creative Commons licence, unless indicated otherwise in a credit line to the material. If material is not included in the article's Creative Commons licence and your intended use is not permitted by statutory regulation or exceeds the permitted use, you will need to obtain permission directly from the copyright holder. To view a copy of this licence, visit http://creativecommons.org/licenses/by/4.0/.

\section{References}

Abdel-Maksoud G, El-Shemy H, Abdel-Hamied M (2019) Investigation methods for evaluating the preservative organic mixtures applied on a Late Period mummy. Archaeol Anthropol Sci 11:1843-1850. https://doi.org/10.1007/s12520-018-0633-7

Beninatto R, De Lucchi O (2016) Chimica organica per artisti e restauratori: sostanze naturali. CREATESPACE

Bennett BC, Prance GT (2000) Introduced plants in the indigenous pharmacopoeia of northern South America. Econ Bot 54:90-102. https:// doi.org/10.1007/BF02866603

Berihuete-Azorín M (2013) First archaeobotanical approach to plant use among Selknam hunter-gatherers (Tierra del Fuego, Argentina). Archaeol Anthropol Sci 5:255-266. https://doi.org/10.1007/ s12520-013-0137-4

Bilimoff M (2003) Enquête sur les plantes magiques. Editions OuestFrance, Rennes

Bouamama H, Noël T, Villard J et al (2006) Antimicrobial activities of the leaf extracts of two Moroccan Cistus L. species. J Ethnopharmacol 104:104-107. https://doi.org/10.1016/j.jep.2005. 08.062

Brandão MGL, Zanetti NNS, Oliveira P et al (2008) Brazilian medicinal plants described by 19th century European naturalists and in the Official Pharmacopoeia. J Ethnopharmacol 120:141-148. https:// doi.org/10.1016/j.jep.2008.08.004

Caravá S, Roldán García C, Vázquez de Agredos-Pascual ML et al (2020) Investigation of modern oil paints through a physico-chemical integrated approach. Emblematic cases from Valencia, Spain. Spectrochim Acta - Part A Mol Biomol Spectrosc 240:118633. https://doi.org/10.1016/j.saa.2020.118633

Castel C, Fernandez X, Lizzani-Cuvelier L et al (2006) Volatile constituents of benzoin gums: Siam and Sumatra, part 2. Study of headspace sampling methods. Flavour Fragr J 21:59-67. https://doi.org/ $10.1002 /$ ffj. 1502

Chen J, Tang C, Zhang R et al (2020) Metabolomics analysis to evaluate the antibacterial activity of the essential oil from the leaves of Cinnamomum camphora (Linn.) Presl. J Ethnopharmacol 253: 112652. https://doi.org/10.1016/j.jep.2020.112652

Colombini MP, Modugno F (2009) Organic mass spectrometry in art and archaeology. John Wiley \& Sons, pp 1-493. https://doi.org/10. 1002/9780470741917

Colombini MP, Giachi G, Modugno F, Ribechini E (2005) Characterisation of organic residues in pottery vessels of the 
Roman age from Antinoe (Egypt). Microchem J 79:83-90. https:// doi.org/10.1016/j.microc.2004.05.004

Colombini MP, Giachi G, Iozzo M, Ribechini E (2009) An Etruscan ointment from Chiusi (Tuscany, Italy): its chemical characterization. J Archaeol Sci 36:1488-1495. https://doi.org/10.1016/j.jas.2009.02. 011

Colombini MP, Modugno F, Gamberini MC et al (2011) A round robin exercise in archaeometry: analysis of a blind sample reproducing a seventeenth century pharmaceutical ointment. Anal Bioanal Chem 401:1847-1860. https://doi.org/10.1007/s00216-011-5105-1

Corp N, Pendry B (2013) The role of Western herbal medicine in the treatment of gout. J Herb Med 3:157-170. https://doi.org/10.1016/j. hermed.2013.08.002

da Cruz Albino R, Simas RC, da Silva Martins K et al (2020) Differentiation of black and white pitch (Burseraceae) oleoresins: a mass spectrometry-based chemoethnotaxonomic study. J Ethnopharmacol 259:112968. https://doi.org/10.1016/j.jep.2020. 112968

de Albuquerque UP, Monteiro JM, Ramos MA, de Amorim ELC (2007) Medicinal and magic plants from a public market in northeastern Brazil. J Ethnopharmacol 110:76-91. https://doi.org/10.1016/j.jep. 2006.09.010

De Vos P (2010) European materia medica in historical texts: longevity of a tradition and implications for future use. J Ethnopharmacol 132: 28-47. https://doi.org/10.1016/j.jep.2010.05.035

Demetzos C, Mitaku S, Loukis A et al (1994) A new drimane sesquiterpene, isomers of manoyl oxide and other volatile constituents from the resin "ladano" of Cistus incanus subsp. Creticus (L.) Heywood. J Essent Oil Res 6:37-41. https://doi.org/10.1080/10412905.1994. 9698322

Duane ZF, Thomas MV (1991) Resin acids of Pinus ponderosa needles. Phytochemistry 30:845-848. https://doi.org/10.1016/00319422(91)85265-2

Escohotado A (1999) Brief history of drugs: from the stone age to the stoned age, 1999. Park Street Press (Historia elemental de las drogas, 1996, Anagrama)

Fadel H, Benayache F, Chalchat J-C et al (2019) Essential oil constituents of Juniperus oxycedrus L. and Cupressus sempervirens L. (Cupressaceae) growing in Aures region of Algeria. Nat Prod Res. https://doi.org/10.1080/14786419.2019.1687473

Figueroa-Suárez MZ, González Christen J, Cardoso-Taketa AT et al (2019) Anti-inflammatory and antihistaminic activity of triterpenoids isolated from Bursera cuneata (Schld1.) Engl. J Ethnopharmacol 238:111786. https://doi.org/10.1016/j.jep.2019. 03.013

Fuster-López L, Izzo FC, Piovesan M, Yusá-Marco DJ, Sperni L, Zendri E (2016) Study of the chemical composition and the mechanical behaviour of 20th century commercial artists' oil paints containing manganese-based pigments. Microchem J 124:962-973. https://doi. org/10.1016/j.microc.2015.08.023

Fuster-López L, Izzo FC, Damato V et al (2019) An insight into the mechanical properties of selected commercial oil and alkyd paint films containing cobalt blue. J Cult Herit 35:225-234. https://doi. org/10.1016/j.culher.2018.12.007

Gamberini MC, Baraldi C, Palazzoli F et al (2008) MicroRaman and infrared spectroscopic characterization of ancient cosmetics. Vib Spectrosc 47:82-90. https://doi.org/10.1016/j.vibspec.2008.02.005

Gamberini MC, Baraldi C, Freguglia G, Baraldi P (2011) Spectral analysis of pharmaceutical formulations prepared according to ancient recipes in comparison with old museum remains. Anal Bioanal Chem 401:1839-1846. https://doi.org/10.1007/s00216-011-5190-1

Gismondi A, D'Agostino A, Di Marco G et al (2020) Back to the roots: dental calculus analysis of the first documented case of coeliac disease. Archaeol Anthropol Sci 12:1-10. https://doi.org/10.1007/ s12520-019-00962-w

Graves R (1992) Los mitos griegos. Alianza editorial, Madrid
Guasch-Jané MR, Ibern-Gómez M, Andrés-Lacueva C et al (2004) Liquid chromatography with mass spectrometry in tandem mode applied for the identification of wine markers in residues from ancient Egyptian vessels. Anal Chem 76:1672-1677. https://doi.org/ $10.1021 / \mathrm{ac} 035082 \mathrm{z}$

Guzman JD (2014) Natural cinnamic acids, synthetic derivatives and hybrids with antimicrobial activity. Molecules 19(12):1929219349. https://doi.org/10.3390/molecules 191219292

Haworth RD, Mavin CR, Sheldrick G (1934) The constituents of guaiacum resin. Part II. Synthesis of dl-guaiaretic acid dimethyl ether. J Chem Soc (Resumed) 1423-1429. https://doi.org/10.1039/jr9340001423

Hosseinihashemi S, Dadpour A, Lashgari A (2017) Antioxidant activity and chemical composition of Juniperus excelsa ssp. polycarpos wood extracts. Nat Prod Res 31:681-685. https://doi.org/10.1080/ 14786419.2016.1209666

Hovaneissian M, Archier P, Mathe C, Vieillescazes C (2006) Contribution de la chimie analytique à l'étude des exsudats végétaux styrax, storax et benjoin. C R Chim 9:1192-1202. https://doi.org/10.1016/j.crci.2005.12.010

Hovaneissian M, Archier P, Mathe C et al (2008) Analytical investigation of styrax and benzoin balsams by HPLC-PAD-fluorimetry and GCMS. Phytochem Anal 19:301-310. https://doi.org/10.1002/pca. 1048

Izzo FC, Zendri E, Bernardi A et al (2013) The study of pitch via gas chromatography-mass spectrometry and Fourier-transformed infrared spectroscopy: the case of the Roman amphoras from Monte Poro, Calabria (Italy). J Archaeol Sci 40:595-600. https://doi.org/ 10.1016/j.jas.2012.06.017

Izzo FC, Balliana E, Pinton F, Zendri E (2014a) A preliminary study of the composition of commercial oil, acrylic and vinyl paints and their behaviour after accelerated ageing conditions. Conserv Sci Cult Heritage 14(1):353-369. https://doi.org/10.6092/issn.1973-9494/ 4753

Izzo FC, Ferriani B, Berg KJ Van den, et al (2014b) 20th century artists' oil paints: the case of the Olii by Lucio Fontana. J Cult Herit https:// doi.org/10.1016/j.culher.2013.11.003

Izzo FC, Zanin C, van Keulen H, da Roit C (2017) From pigments to paints: studying original materials from the atelier of the artist Mariano Fortuny y Madrazo. Int J Conserv Sci 8:547-564. https://www. scopus.com/record/display.uri?eid=2-s2.0-85037748692\&origin= resultslist

Jamshidi-Kia F, Lorigooini Z, Amini-Khoei H (2018) Medicinal plants: past history and future perspective. J Herb Med Pharmacol 7:1-7. https://doi.org/10.15171/jhp.2018.01

Jarić S, Popović Z, Mačukanović-Jocić M et al (2007) An ethnobotanical study on the usage of wild medicinal herbs from Kopaonik Mountain (Central Serbia). J Ethnopharmacol 111:160-175. https://doi.org/10.1016/j.jep.2006.11.007

Junius M (1985) The practical handbook of plant alchemy: an Herbalists's guide to preparing medicinal essences, tinctures, and elixirs. Healing Arts Press, Rochester

Kratochvil JF, Burris RH, Seikel MK, Harkin JM (1971) Isolation and characterization of $\alpha$-guaiaconic acid and the nature of guaiacum blue. Phytochemistry 10:2529-2531. https://doi.org/10.1016/ S0031-9422(00)89901-X

Kusuma HS, Mahfud M (2017) GC-MS analysis of essential oil of Pogostemon cablin growing in Indonesia extracted by microwaveassisted hydrodistillation. Int Food Res J 24:1525-1528

Langenheim JH (2013) Plant resins: chemistry, evolution, ecology, and ethnobotany. Timber Press, Portland

Lardos A, Prieto-Garcia J, Heinrich M (2011) Resins and gums in historical iatrosophia texts from Cyprus-a botanical and medicopharmacological approach. Front Pharmacol 2:32. https://doi.org/ 10.3389/fphar.2011.00032 
Liu Y, Dao Z, Yang C et al (2009) Medicinal plants used by Tibetans in Shangri-la, Yunnan, China. J Ethnobiol Ethnomed 5:15. https://doi. org/10.1186/1746-4269-5-15

Lobovikov Katz A, Moropoulou A, Konstanti A, Calderón P, Grieken RV, Worth S, Cassar J, Angelis RD, Biscontin G, Izzo FC (2014) Tangible versus intangible in e-learning on cultural heritage: from online learning to on-site study of historic sites, Progress in Cultural Heritage: Documentation, Preservation, and Protection, vol 8740. Springer International Publishing, pp 819-828. https://doi.org/10. 1007/978-3-319-13695-0

Lodi GC, Borsato G, Vázquez de Ágredos Pascual ML et al (2020) Disclosing the composition of unknown historical drug formulations: an emblematic case from the Spezieria of St. Maria della Scala in Rome. Anal Bioanal Chem. https://doi.org/10.1007/ s00216-020-02893-1

Lucero-Gómez P, Mathe C, Vieillescazes C et al (2014) Analysis of Mexican reference standards for Bursera spp. resins by Gas Chromatography-Mass Spectrometry and application to archaeological objects. J Archaeol Sci 41:679-690. https://doi.org/10.1016/j. jas.2013.07.021

Mackonochie M, Heinrich M (2019) Materia medica chests: investigating the 19th century use of botanicals by different medical professions. J Herb Med 16:100255. https://doi.org/10.1016/j.hermed.2019. 100255

Maderna E (2012) Medichesse. La vocazione femminile alla cura. Aboca, Sansepolcro

Mazzei R, Leonti M, Spadafora S et al (2020) A review of the antimicrobial potential of herbal drugs used in popular Italian medicine $(1850 \mathrm{~s}-1950 \mathrm{~s})$ to treat bacterial skin diseases. J Ethnopharmacol 250:112443. https://doi.org/10.1016/j.jep.2019.112443

Medeiros MFT, De Albuquerque UP (2012) The pharmacy of the Benedictine monks: the use of medicinal plants in Northeast Brazil during the nineteenth century (1823-1829). J Ethnopharmacol 139: 280-286. https://doi.org/10.1016/j.jep.2011.11.014

Meikle RD (1977-1985) Flora of Cyprus. The Bentham-Moxon Trust Royal Botanic Gardens, Kew, vol. 1, p 2

Merali Z, Cayer C, Kent P et al (2018) Sacred Maya incense, copal (Protium copal - Burseraceae), has antianxiety effects in animal models. J Ethnopharmacol 216:63-70. https://doi.org/10.1016/j. jep.2018.01.027

Mills J, White R (1994) Organic chemistry of museum objects. Butterworth \& Co, Oxford

Mizzoni F, Cesaro SN (2007) Study of the organic residue from a 2600year old Etruscan plumpekanne. Spectrochim Acta - Part A Mol Biomol Spectrosc 68:377-381. https://doi.org/10.1016/j.saa.2006. 12.005

Modugno F, Ribechini E, Colombini MP (2006) Aromatic resin characterisation by gas chromatography-mass spectrometry. Raw and archaeological materials. J Chromatogr A 1134:298-304. https://doi. org/10.1016/j.chroma.2006.09.010

Munger RS (1949) Guaiacum, the Holy Wood from the New World. J Hist Med Allied Sci 4:196-229

Neamsuvan O, Tuwaemaengae T, Bensulong F et al (2012) A survey of folk remedies for gastrointestinal tract diseases from Thailand's three southern border provinces. J Ethnopharmacol 144:11-21. https://doi.org/10.1016/j.jep.2012.07.043

Nitrihual Valdebenito L (2015) CASTAÑARES, Wenceslao (2014). Historia del pensamiento semiótico. La antigüedad grecolatina. Perspect la Comun 8:137-142

Noda N, Kogetsu H, Kawasaki T, Miyahara K (1990) Scammonins I and II, the resin glycosides of radix scammoniae from Convolvulus scammonia. Phytochemistry 29:3565-3569. https://doi.org/10. 1016/0031-9422(90)85277-M

Oliveira C, Araújo A, Ribeiro A, Delerue-Matos C (2019) Chromatographic analysis of honey ceramic artefacts. Archaeol
Anthropol Sci 11:959-971. https://doi.org/10.1007/s12520-0170585-3

Pérez-Arantegui J, Cepriá G, Ribechini E et al (2009) Colorants and oils in Roman make-ups-an eye witness account. TrAC - Trends Anal Chem 28:1019-1028. https://doi.org/10.1016/j.trac.2009.05.006

Petrović M, Hernando MD, Díaz-Cruz MS, Barceló D (2005) Liquid chromatography-tandem mass spectrometry for the analysis of pharmaceutical residues in environmental samples: a review. J Chromatogr A 1067:1-14. https://doi.org/10.1016/j.chroma.2004. 10.110

Rey M (2008) Historia de las hierbas mágicas y medicinales: plantas alucinógenas, hongos psicoactivos visionarias, hierbas fúnebres.. todos los secretos sobre las propiedades y virtudes ocultas del ancestral mundo vegetal

Reyes-García V, Huanca T, Vadez V, Leonard W, Wilkie D (2006) Cultural, practical, and economic value of wild plants: a quantitative study in the Bolivian Amazon 1. Econ Bot 60(1):62-74. https://doi. org/10.1663/0013-0001(2006)60[62:CPAEVO]2.0.CO;2

Ribechini E, Modugno F, Colombini MP, Evershed RP (2008) Gas chromatographic and mass spectrometric investigations of organic residues from Roman glass unguentaria. J Chromatogr A 1183:158 169. https://doi.org/10.1016/j.chroma.2007.12.090

Ribechini E, Orsini S, Silvano F, Colombini MP (2009) Py-GC/MS, GC/ MS and FTIR investigations on LATE Roman-Egyptian adhesives from opus sectile: new insights into ancient recipes and technologies. Anal Chim Acta 638:79-87. https://doi.org/10.1016/j.aca. 2009.02.004

Ribechini E, Modugno F, Pérez-Arantegui J, Colombini MP (2011a) Discovering the composition of ancient cosmetics and remedies: analytical techniques and materials. Anal Bioanal Chem 401: 1727-1738. https://doi.org/10.1007/s00216-011-5112-2

Ribechini E, Pérez-Arantegui J, Colombini MP (2011b) Gas chromatography/mass spectrometry and pyrolysis-gas chromatography/mass spectrometry for the chemical characterisation of modern and archaeological figs (Ficus carica). J Chromatogr A 1218:3915-3922. https://doi.org/10.1016/j.chroma. 2011.04.052

Rigon C, Izzo FC, Vázquez De Ágredos Pascual ML et al (2020) New results in ancient Maya rituals researches: the study of human painted bones fragments from Calakmul archaeological site (Mexico). J Archaeol Sci Rep 32:102418. https://doi.org/10.1016/ j.jasrep. 2020.102418

Riva E (2001) History and science camphor a very rare perfume. Natural $1: 78-79$

Rivera D, Verde A, Fajardo J et al (2019) Ethnopharmacology in the Upper Guadiana River area (Castile-La Mancha, Spain). J Ethnopharmacol 241:111968. https://doi.org/10.1016/j.jep.2019. 111968

Saliu F, Modugno F, Orlandi M, Colombini MP (2011) HPLC-APCI-MS analysis of triacylglycerols (TAGs) in historical pharmaceutical ointments from the eighteenth century. Anal Bioanal Chem 401: 1785-1800. https://doi.org/10.1007/s00216-011-5179-9

Sauerwein M, Shimimoura K (1990) 17 0-Methylyohimbine and vallesiachotamine of Amsonia elliptica. Phytochemistry 29:33773379

Shahzad Aslam M, Choudhary BA, Uzair M, Subhan Ijaz A (2013) Phytochemical and ethno-pharmacological review of the genus Araucaria-review. Trop J Pharm Res 12:651-659. https://doi.org/ 10.4314/tjpr.v12i4.31

Simoneit BRT, Otto A, Kusumoto N, Basinger JF (2016) Biomarker compositions of Glyptostrobus and Metasequoia (Cupressaceae) fossils from the Eocene Buchanan Lake Formation, Axel Heiberg Island, Nunavut, Canada reflect diagenesis from terpenoids of their related extant species. Rev Palaeobot Palynol 235:81-93. https:// doi.org/10.1016/j.revpalbo.2016.07.012 
Taylor D (2016) The pharmaceutical industry and the future of drug development. https://doi.org/10.1039/9781782622345-00001

Thomas E, Vandebroek I, Sanca S, Van Damme P (2009) Cultural significance of medicinal plant families and species among Quechua farmers in Apillapampa, Bolivia. J Ethnopharmacol 122:60-67. https://doi.org/10.1016/j.jep.2008.11.021

Vargová L, Vymazalová K, Horáčková L (2019) A brief history of syphilis in the Czech Lands. Archaeol Anthropol Sci 11:521-530. https:// doi.org/10.1007/s12520-017-0558-6

Vázquez de Ágredos Pascual ML, Iranzo Rojo L, Van-Elslande E, et al (2017) Science, art and mythological Greco-Roman beliefs in the ancient pharmacy of Santa Maria Della Scala, Rome. In: Iulian Rusu MTN, Apostolescu END and N (eds) ESRARC 2017 9th European symposium on religious art, restoration \& conservation. KERMES, Torino, pp 116-120

Vázquez de Ágredos Pascual ML, Cavallo G, Pagiotti R et al (2018) Tradition and renovation in the ancient drugs of the Spezieria di Santa Maria Della Scala between scientific knowledge and magical thought. Eur J Sci Theol 14:3-12
Vázquez de Ágredos Pascual ML, Vidal Lorenzo C, Radnicka K, Źrałka J, Velásquez JL, 2019) Between two worlds: colors and techniques of the mural paintings preserved in a colonial house in Chajul (El quiche department, Guatemala), Science and Digital Technology for Cultural Heritage; Interdisciplinary Approach to Diagnosis, Vulnerability, Risk Assessment and Graphic Information Models Proceedings of the 4th International Congress Science and Technology for the conservation of cultural heritage, TECHNOHERITAGE 2019, pp. 210-214

Verma RS, Padalia RC, Chauhan A, Singh VR (2019) Chemical composition of leaves, inflorescence, whole aerial-parts and root essential oils of patchouli \{Pogostemon cablin (Blanco) Benth.\}. J Essent Oil Res 31:319-325. https://doi.org/10.1080/10412905.2019.1566100

Publisher's note Springer Nature remains neutral with regard to jurisdictional claims in published maps and institutional affiliations. 